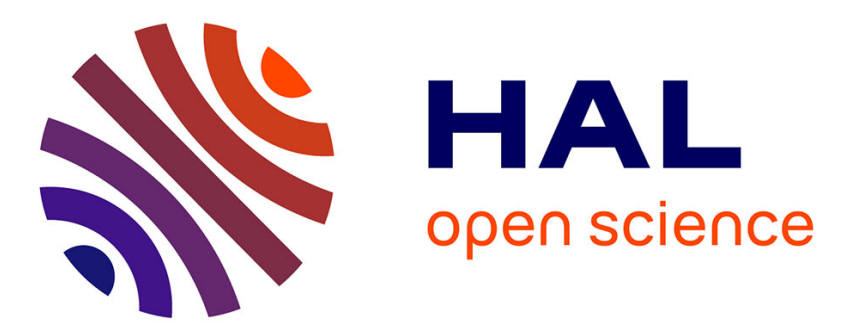

\title{
Colwellia and sulfur-oxidizing bacteria: An unusual dual symbiosis in a Terua mussel (Mytilidae: Bathymodiolinae) from whale falls in the Antilles arc
} Sébastien Duperron, Olivier Gros

\section{- To cite this version:}

Sébastien Duperron, Olivier Gros. Colwellia and sulfur-oxidizing bacteria: An unusual dual symbiosis in a Terua mussel (Mytilidae: Bathymodiolinae) from whale falls in the Antilles arc. Deep Sea Research Part I: Oceanographic Research Papers, 2016, 115, pp.112-122. 10.1016/j.dsr.2016.05.012 . hal-01336943

\section{HAL Id: hal-01336943 \\ https://hal.sorbonne-universite.fr/hal-01336943}

Submitted on 24 Jun 2016

HAL is a multi-disciplinary open access archive for the deposit and dissemination of scientific research documents, whether they are published or not. The documents may come from teaching and research institutions in France or abroad, or from public or private research centers.
L'archive ouverte pluridisciplinaire HAL, est destinée au dépôt et à la diffusion de documents scientifiques de niveau recherche, publiés ou non, émanant des établissements d'enseignement et de recherche français ou étrangers, des laboratoires publics ou privés. 
Colwellia and sulfur-oxidizing bacteria: an unusual dual symbiosis in a Terua mussel (Mytilidae: Bathymodiolinae) from whale falls in the Antilles arc

Sébastien Duperron ${ }^{1,2^{*}}$ and Olivier Gros ${ }^{3,4}$

$5 \quad{ }^{1}$ Sorbonne Universités, UPMC Université Paris 06, UMR7208 Laboratoire biologie des organismes et écosystèmes aquatiques (UPMC CNRS MNHN IRD CAEN), 7 quai St Bernard, 75005 Paris, France

${ }^{2}$ Institut Universitaire de France, Paris, France

${ }^{3}$ Institut de Biologie Paris-Seine, UMR 7138 - Evolution Paris-Seine, Equipe Biologie de la

10 Mangrove. Université des Antilles, UFR des Sciences Exactes et Naturelles, Département de Biologie, BP 592. 97159 Pointe-à-Pitre cedex, Guadeloupe, France.

${ }^{4} \mathrm{C}_{3} \mathrm{MAG}$, UFR des Sciences Exactes et Naturelles, Université des Antilles, BP 592. 97159 Pointe-àPitre, Guadeloupe (French West Indies).

$15{ }^{*}$ Corresponding author

E-mail: sebastien.duperron@upmc.fr

Running title: Dual symbiosis in mussels colonizing sunken bones in Caribbean

Keywords: Caribbean sea, symbiosis, whale falls, sulfur-oxidizing bacteria, Colwellia, Terua. 


\section{Abstract}

Seven individuals of a single morphotype of mussels (Bivalvia: Mytilidae) were found attached to a naturally sunken whale intervertebral disk collected in Guadeloupe (Caribbean) at 800 $\mathrm{m}$ depth. These specimens resemble small Idas mussels which are found worldwide at cold seeps and hydrothermal vents, and typically harbour ectosymbiotic bacteria on their gills upon which they depend for nutrition. Based on multi-locus gene sequencing, these specimens appear to belong to a new species closely related to two species now included within the genus Terua. Unexpectedly, its closest relatives are found in the Pacific, questioning how this species has reached the Antilles arc.

30 Based on marker gene sequence analysis, electron and fluorescence microscopy, Terua n. sp. harbours two distinct and abundant extracellular bacterial symbionts located between microvilli at the apical surface of host gill epithelial cells. One is a sulfur-oxidizing bacterium similar to the symbionts previously identified in several deep-sea mussels, while the other is related to Colwellia species, a group of cold-adapted heterotrophic bacteria able to degrade organic compounds. This

35 study provides the first evidence for the existence of a dual symbiosis in mussels from whale fall ecosystems in the Caribbean. The evolutionary history of Terua n. sp. and potential role of its Colwellia symbionts are discussed.

\section{Introduction}

Large mussels associated with deep-sea hydrothermal vents and cold seeps have been studied since their discovery in the late 1970s. Their abundance at many sites and their nutritional reliance on dense populations of gill-associated bacterial symbionts which use reduced sulfur or methane to produce their organic matter attracted interest from many researchers. They form the clade Bathymodiolinae, named after the genus Bathymodiolus (Kenk \& Wilson, 1985) in which most large mussels are included. Many papers have investigated how these symbiotic bivalves could thrive in a priori inhospitable habitats and how they had evolved (Dubilier et al., 2008; Duperron, 2010). Over the last decade smaller mussels, some described in the $19^{\text {th }}$ century and overlooked since then, were shown to also belong to the Bathymodiolinae clade (Lorion et al. 2010, 2013; Thubaut et al. 2013). They live in reducing habitats including vents and

50 seeps, but also on sunken carcasses of large animals and on wood falls, the decaying of which releases reduced compounds including sulfide and methane. The classification of small mussels is challenging because genus names do not overlap with gene phylogeny-based clades, but small species are of prime importance if we are to understand the evolution of deep-sea symbiont-bearing mussels. Indeed, large mussels cluster within a limited number of terminal clades, appearing as 
55 derived specialized forms, while the rest of the Bathymodiolinae phylogeny consists of various groups of small mussels. Biologically-speaking, apart from their small size, they share important features with large mussels, including the presence of bacterial symbionts in their gills (Deming et al. 1997; Gros and Gaill 2007; Duperron et al. 2008b; Southward 2008). However their symbioses seem to be more diverse and flexible. Large mussels usually have one to four types of bacteria

60 located inside their gill epithelial cells. Small mussels on the other hand can display intra- or extracellular bacteria, a greater diversity of symbionts with up to 6 distinct types co-existing in the gills of Idas modiolaeformis, not restricted to sulfur- and methane-oxidizers, and the composition of bacterial communities can vary between sites for a given species (Duperron et al. 2008a; Laming et al. 2015b). Unfortunately, because of the patchy and unpredictable occurrence of their habitats, small mussels are often collected by chance in very limited numbers. Nevertheless their study yields important information for our understanding of the diversity, biogeography and evolution of the fauna colonizing deep-sea reducing habitats.

Seven species of Bathymodiolinae mussels are currently reported from the Gulf of Mexico and Antilles arc, all from cold seep habitats. Four are large Bathymodiolus (B. keckerae, B.

70 boomerang, B. brooksi, B. childressi and a yet unnamed species), and two are smaller species, namely Tamu fisheri usually collected from 540-700 $\mathrm{m}$ depth associated with vestimentiferan tubeworm bushes, and Idas macdonaldi from $650 \mathrm{~m}$ depth (Gustafson et al. 1998; Faure et al., 2015). Dell (1987) also mentions Idas dalli E.A. Smith 1885 sampled from the Culebra Island (Porto Rico, West Indies) during the Challenger expedition, but little data is available. Seven mussel

75 individuals representing a single morphotype were recently found attached to an inter-vertebral disk of a naturally sunken whale collected near Guadeloupe (Caribbean) at $800 \mathrm{~m}$ depth. In this study we test whether these represent a new species, or one of the 7 previously documented from the region, using multiple marker gene sequencing and phylogeny. We also characterize associated bacterial symbionts using electron microscopy, marker gene sequencing and fluorescence in situ

80 hybridization (FISH). Results are discussed with a special emphasis on mussel biogeography, and on the potential role of the identified symbionts. This study is the first investigation of boneassociated symbiotic mussels from the Antilles arc.

\section{Materials and methods}

85

\section{Sample collection and preparation}

One inter-vertebral disk from a whale carcass was collected using a beam-trawl 780-820 m depth during the karubenthos 2 cruise (June 2015, chief scientist: P. Bouchet) around Guadeloupe in 
the Caribbean $\left[16^{\circ} 23^{\prime} \mathrm{N}, 60^{\circ} 46^{\prime} \mathrm{W}\right]$. Mussel individuals up to $2 \mathrm{~cm}$ in length were found attached to

90 the surface of a spinal disk obtained from a unique naturally submerged whale carcass. Mussel samples were processed onboard within 1 hour after collection.

Six mussel individuals were stored in $100 \%$ ethanol for molecular investigation of bacterial diversity (see below) after severing adductor muscles. One individual was prepared for electron microscopy. The two adductor muscles were severed in order to open the bivalve, then the whole 95 animal was pre-fixed in 2.5\% glutaraldehyde / 0.1M cacodylate buffer (pH 7.2) adjusted to 900 mOsM with $\mathrm{NaCl}$ and $\mathrm{CaCl}_{2}$ and stored at $4{ }^{\circ} \mathrm{C}$. Two weeks later, after returning to the laboratory, the gills were dissected into three parts. Scanning Electron Microscope (SEM) and Transmission Electron Microscope (TEM) were performed to detect possible symbiosis. Samples for SEM observations were rinsed twice in the same buffer then dehydrated in graded concentrations of acetone, critical point dried in $\mathrm{CO}_{2}$ and sputter-coated with gold before observation with a FEI Quanta 250 at 20kV. For TEM observations, samples were rinsed in the same buffer, fixed for 45 minutes at room temperature in $1 \%$ osmium tetroxide in the same buffer with a final osmolarity adjusted to $1000 \mathrm{mOsm}$, then rinsed in distilled water and post-fixed with $2 \%$ aqueous uranyl acetate for one more hour at RT before embedding in epon-araldite resin and observation in a FEI Quanta 105250 at $15 \mathrm{kV}$ under the STEM mode.

\section{Energy-dispersive X-ray spectroscopy (EDXs) analysis}

In order to detect elemental compounds from the gill (such as sulfur), the gill fragment stored in the fixative solution was observed using an Environmental Scanning Electron Microscope (FEI Quanta 250) operating at $10 \mathrm{kV}$ under an environmental pressure of 7 torr at $8^{\circ} \mathrm{C}$. EDX spectra were obtained using a X-max $50 \mathrm{~mm}^{2}$ Oxford SDD detector. Gills were rinsed briefly in distilled water (to remove salts) and observed without prior dehydration.

\section{Gene sequence analysis}

115 DNA was extracted from the gill tissue from two specimens according to the protocol previously described (Duperron et al. 2005). Fragments of host genes encoding H3 histone, 28S rRNA, mitochondrial cytochrome oxidase I (mtCOI) and mitochondrial 16S rRNA (mt16S), and fragments of bacterial genes encoding 16S rRNA and APS reductase were amplified by PCR. Products were cloned (products from 3 parallel PCR were pooled prior to cloning for bacterial 16S rRNA) using the PCR ${ }^{\circledR}$ 2.1-TOPO TA cloning kit (Invitrogen, CA), and inserts from selected clones were sequenced by GATC Biotech (Germany). PCR primers, cycling conditions and number of analysed clones are summarized in table 1. Sequences were deposited under GENBANK accession numbers 


\section{KU747145-KU747153.}

For each gene, representative sequences, their best hits according to BLAST (Altschul et al. 1990)

125 and selected available sequences were aligned using ClustalX. Alignments were manually curated and phylogenetic reconstructions were performed using Mega v.6 using a Maximum Likelihood (ML) approach under a General Time Reversible (GTR) model. To account for different substitution rates among sites, gamma-distributed rates with 5 categories and invariants were included. For host genes, a multi-gene phylogeny was produced using concatenated sequences of mtCOI, mt16S and $130 \mathrm{H} 3$.

\section{Fluorescence in situ hybridization (FISH)}

Specimens were embedded in Steedman's wax or LR-White according to described protocols, and sectioned using a microtome (Thermo). FISH was performed using standard probes Eub-338 and

Non-338 as positive and negative controls, respectively. Probe Bthio-193 displayed perfect match with the 16S rRNA-encoding sequence related to sulfur-oxidizing (SOX) bacteria and was used to test for its presence in the tissues (5'-CGAAGATCCTCCACTTTA-3' (Duperron et al. 2007) ). Probe Alt1413 (5'-TTTGCATCCCACTCCCAT-3') showed no mismatch to the other, Colwelliarelated abundant sequence in clone libraries and was used to test for the presence of this potential second bacterium (Eilers et al. 2000). It was designed to target the genus Alteromonas but also matches one third of available Colwellia sequences according to the ProbeMatch function of Ribosomal Database Project (Cole et al. 2009).

Hybridizations were performed according to Duperron et al. (2005) using buffers containing 30 and 40\% formamide, and probes were labelled with Cy-3 or Cy-5. Slides were counterstained

145 with DAPI, and observed under an Olympus BX61 epifluorescence microscope (Olympus, Japan).

\section{Results}

\section{Host features}

The 7 small mytilids (shell length between 9 and $12 \mathrm{~mm}$ long) displayed identical shell features, including a pink whole prodissoconch $445 \pm 13 \mu \mathrm{m}$ in length (Figs. 1A, 2A-D) and an adult dissoconch appearing smooth under a binocular microscope. According to SEM views, prodissoconch I was small $(\sim 92 \pm 11 \mu \mathrm{m})$ and the prodissoconch II measured $445 \pm 13 \mu \mathrm{m}$ with several concentric growth lines (maximum length between two adjacent lines: $\sim 9 \mu \mathrm{m}$ ). The visceral mass of two individuals (shell lengths of 10 and $12 \mathrm{~mm}$ ) was filled with oocytes (not shown) indicating that they were adults, 6 fold above the size at maturity reported for the deep sea Idas 
modiolaeformis (Laming et al. 2014). Mean oocyte diameter was $63 \pm 5.7 \mu \mathrm{m}$ (not shown).

\section{Molecular identification of mussels}

The two specimens from which host genes were sequenced displayed identical sequences for all 4 genes based on 6 to 12 clones (table 1). The sequence encoding $28 \mathrm{~S}$ rRNA displayed only 1 out of 1002 base difference with sequences from Adipicola pacifica and ESU T, and above 99\% identity with many sequences from various mussels. Due to this, 28S rRNA was not included in the concatenated analysis. Nucleotide sequences encoding mt16S, mtCOI and H3 all displayed ESU T as their best hit with $97 \%, 89 \%$ and 100\% sequence similarity, respectively. Adipicola pacifica usually came second with 93\%, 84\% and 99\%, respectively. Phylogenetic reconstructions obtained for each gene placed ESU T, collected from bones at depths between 800 and $1060 \mathrm{~m}$ near the Vanuatu (Lorion et al. 2013), as a sister group to the mussels from this study with high bootstrap values (above 95\%, not shown). The tree based on concatenate gene sequences confirmed that our specimens were closely related to ESU sp. T, and that this group clustered with Adipicola pacifica, both nodes being supported by bootstrap values above $98 \%$ (Fig. 3).

\section{Ultrastructural analysis of gill tissue}

The overall structure of gill filaments in all specimens was comparable to that described previously in other mussel morphotypes (Gros and Gaill 2007; Duperron et al. 2008b). According to SEM views, the creamy colored gills, which cover the visceral mass, are organized in consecutive gill filaments (Figs. 1B, 1D). The surface of the gills contains a dense covering of cilia that could carry food along a food groove (Figs. 1D-E) to the mouth region. The presence of such groove could suggest a mixotrophic feeding mode in this species. The ciliated zone is similar to that described in other mytilid species with typical frontal, latero-frontal, and lateral ciliated cells (Fig. 4A). In the ciliated zone, the core of each filament is occupied by a collagen axis which encloses few fibroblasts, whereas, in the lateral zone, it is occupied by connective tissue and a blood lacuna (Figs. 4B-C). The intermediary zone is short as the first cell in contact with the ciliated zone contained bacteria on its surface for all the samples studied (Figs. 1F, 4C). The ciliated zone always appeared 185 devoid of bacteria.

A few gill filaments were analyzed in EDXs using an environmental SEM (Fig. 1B) searching for elemental compounds. The analysis showed that sulfur was one of the main elements detected from the gills where it was much more abundant than in mantle or foot (Fig. 1C and D), suggesting the putative presence of sulfur-oxidizing bacterial symbionts. Furthermore, ultrastructural analyses of thin sections of the specimens observed by TEM confirmed that bacteria 
were associated with the gill tissue and were mostly extracellular (Figs. 4B-C, 5C). Moreover, bacteria with a similar morphotype compared to the extracellular ones could be present within vacuoles (Figs. 4C, 5A, 5C). Gill epithelial cells displayed a basal nucleus (Figs. 4C, 5B), few lysosome-like structures (Figs. 5A, C) and numerous bacteria inside vacuoles (Figs. 4B-C, 5A) or between the microvilli in their apical pole (Fig. 4C). The lateral zone of each filament consisted of a single cell type bearing the bacterial symbionts (Figs. $4 \& 5$ ). No intercalary cells and/or mucocytes could be detected in the samples analyzed.

Individually, the bacteria were small and rod shaped ( $1 \mu \mathrm{m}$ length, $0.3 \mu \mathrm{m}$ thick) with a cell wall typical of gram-negative bacteria (Figs. 4C, 5C). No stacked intracellular membranes typical of

200 methanotrophic symbionts were seen. Differences in the shape of individual bacteria are due to section orientation. However, two morphotypes could be distinguished from the gill sections. The first one was characterized by a ribosome-rich cytoplasm appearing as a black area, localized at the periphery of the cell while the center of the cell containing the DNA was clearer (Figs. 4C, 5A-C). This morphology is unusual compared to previously described sulfur-oxidizing bacterial symbionts 205 of bivalves. The second morphotype was characterized by a clearer cytoplasm (Figs. 4C, 5A-C). Both morphotypes seem to be equally (and randomly) distributed through the lateral zone of each gill filament. The first bacteriocytes contained extracellular, but no envacuolated bacteria, as shown by SEM (Fig. 1E) or TEM (Fig. 5B) views.

\section{Molecular identification of associated bacteria}

Two 16S rRNA-encoding gene sequences dominated clone libraries in both specimens investigated. The first phylotype displayed 10 out of 1501 base differences with Colwellia sp. ZS4-15 (FJ889666) cultured from Antarctic intertidal sediment (Yu et al. 2010), and above 99\% sequence identity with various Colwellia including C. psychroerythraea $34 \mathrm{H}$ of which the full genome is

215 available (CP000083 (Methe et al. 2005)) and C. rossensis from pack ice (AY167311 (Brinkmeyer et al. 2003)). The second phylotype displayed $99 \%$ identical positions with various sequences recovered from sulfur-oxidizing symbionts associated with deep-sea mussels, differing from clone M1.2 from Idas modiolaeformis by 11 out of 1492 aligned positions (Duperron et al. 2008a). The phylogenetic reconstruction confirmed these affiliations (Fig. 6). The Colwellia- and SOX-related

220 phylotypes represented respectively 62.9 and $35.7 \%$ of clone sequences in specimen 1 (140 clones), and 41.2 and 58.0\% in specimen 2 (131 clones). The three remaining clones (KU747151-3) corresponded to three distinct Epsilonproteobacteria related to various deep-sea bacteria. Several distinct sequences were obtained in clone libraries of the APS reductase-encoding gene. The most abundant, representing 13 of the 21 clones, was $93 \%$ and $98 \%$ (nucleotide and amino acids, 
225 respectively) similar to sequences previously obtained from mussel-associated SOX symbionts, suggesting that it could belong to the SOX-related bacterium identified herein.

\section{FISH-based identification of potential symbionts}

Hybridizations using the probe Eub-338 confirmed the presence of dense bacterial

230 populations associated with the lateral zone of gill filaments in all 3 specimens investigated. Probe Bthio-193 targeting SOX symbionts labelled only a fraction of the bacteria labelled with the general probe Eub-338 (Figs. 7A-B). SOX signals could usually be seen spanning a number of neighbouring bacteriocytes, while large areas of the lateral zone were devoid of such signals. Probe Alt1413 targeting the Colwellia-related phylotype hybridized with those bacteria that were not labelled by Bthio-193 (Figs. 7C-D). Due to inappropriate fixation, FISH signals were not as sharp as could be, yet signals from probes Alt1413 and Bthio-193 did not seem to overlap, suggesting they succeeded in distinguishing the two main phylotypes identified in clone libraries.

\section{Discussion}

240

\section{Unexpected occurrence of Terua $\mathrm{n}$. sp. in the Antilles arc}

According to various authors, the lack of specific shell features makes the latter poor predictors of species relatedness in small deep-sea mussels (Won et al., 2008; Lorion et al. 2010). Marker gene sequence analysis has thus proven to be the most useful tool to properly assign species. Sequence-

245 based identification has revealed that most morphology-based genera within the Bathymodiolinae were not monophyletic. Genus names are thus of little help when describing mussel evolutionary relationships (Thubaut et al. 2013). Specimens from the present study clustered between Adipicola pacifica and ESU T. Their mtCOI nucleotide sequences differed by 16.4 and $11.4 \%$ from those of $A$. pacifica and ESU T, respectively, suggesting that they belong to a distinct, yet-to-be described

250 species. Thubaut and co-workers recently suggested that $A$. pacifica and ESU T should be classified within the genus Terua initially described by Dall and his colleagues in 1938 (Thubaut et al. 2013). Following their recommendation we refer to our specimens as Terua n. sp. Guadeloupe in the following sections. Small Bathymodiolinae occur in the North West Atlantic and Gulf of Mexico, including Idas macdonaldi (sister species to I. modiolaeformis in figure 3) and Tamu fisheri, but

255 they are not closely related to Terua $\mathrm{n}$. sp. The closest relatives of Terua $\mathrm{n}$. sp. are reported from the Pacific Ocean and are not related to any species recorded from the Antilles arc. Based on the 3 fossil-based calibrations used by Lorion et al. (2013) and using the RelTime method implemented in MEGA 6, Terua n. sp. Guadeloupe diverged from ESU T around 6.2 MYA. This is consistent 
with the closure of the Isthmus of Panama. A date around 8-12 MYA is often used as a time

260 calibration in biogeography studies (Plouviez et al. 2013), however several studies question these dates and suggest final closure of the seaway later, possibly as late as 3 MYA (Bartoli et al. 2005). The divergence time estimated here suggests that colonization of the Gulf of Mexico by ancestors of Terua $\mathrm{n}$. sp. could have happened before the seaway closed.

The shell provides another type of information. Here, the prodissoconch I (PI) measured $92 \pm 11 \mu \mathrm{m}$,

265 and the prodissoconch II (PII) measured $445 \mu \mathrm{m} \pm 13 \mu \mathrm{m}$, within the range of values published for several other small Bathymodiolinae including Idas modiolaeformis, I. argenteus, I. iwaotakii or I. simpsoni (74 to $96 \mu \mathrm{m}$ for PI, ad 379 to 544 for PII, (Laming et al. 2015a)). Based on these values, it can be assumed that Terua $\mathrm{n}$. sp. displays dispersal features similar to those reported in other clades within the Bathymodiolinae. The relatively small size of the oocytes (indeed with a low vitelline content) observed in 2 individuals, as well as the small PI size both confirm planktotrophic development in this new species of Terua. Similar oocyte diameter $(41.5 \pm 7.5 \mu \mathrm{m})$ was described in the small mytilid Idas modioliformis which displays a planktotrophic development (Gaudron et al., 2012). Based on much larger PII compared to PI sizes, these previous studies also inferred that larval life prior to settlement could potentially last for several months at low environmental 275 temperatures.

\section{An unusual type of dual symbiosis}

According to clone libraries and in situ hybridizations on gill sections, two dominant bacteria occur in Terua n. sp. Guadeloupe. One is a sulfur-oxidizer closely related to various symbionts previously

280 identified in mussels. Its capability to perform sulfur oxidation is further supported by identification of an APS reductase sequence displaying high similarity with those found in other SOX symbionts, and by the identification of abundant sulfur in the gills in EDXs analysis. Sulfur-oxidizing symbionts are reported in most Bathymodiolinae investigated to date in which they contribute to nutrition and, arguably, to sulfide detoxification (Distel et al. 1988; Dubilier et al. 2008). The second bacterium identified is a close relative of several Colwellia species. With a 16S rRNA sequence similarity above $99 \%$, it can confidently be classified within this genus. Ultrastructural analysis indicates that bacteria are extracellular, a common feature of mussels associated with organic falls (Gros and Gaill 2007; Duperron et al. 2008b). Clone libraries yielded similar amounts of the two 16S rRNA phylotypes, and FISH confirmed that both were abundant with possible

290 dominance of the Colwellia-related bacterium in the investigated specimens. Both types of bacteria are thus likely to play a significant role in the association. In a study of mussels from whale falls near Japan, Fujiwara and colleagues also identified sulfur-oxidizing and Colwellia-related 
(symbiont C) bacteria as extracellular symbionts in the gills of Adipicola pacifica (Fujiwara et al. 2010). The 16S rRNA sequence from the latter symbiont (AB539012) is only 93.2\% similar to the

295 sequence reported herein and not its closest relative in the phylogenetic tree, and their FISH results indicated dominance of the sulfur-oxidizers. But overall it is reasonable to assume that the closely related A. pacifica and Terua n. sp. Guadeloupe which both live on whale carcasses share a similar type of dual symbiosis, different from the classical examples involving sulfur- and methaneoxidizers described in large vent and seep mussels (Fisher et al. 1993; Distel et al., 1995). Whether this unusual type of dual symbiosis is a peculiar feature of the Terua lineage or is strictly habitatdependent needs to be further tested, notably on ESU T for which no data is currently available.

\section{Potential significance of Colwellia-related bacterial symbionts in a dual symbiosis}

The genus Colwellia currently comprises 13 described species, with many more sequences from environmental samples reported in databases. Colwellia are adapted to cold marine environments, and include no known pathogen. The two closest described relatives of the Terua n. sp. Guadeloupe symbiont are C. rossensis and C. psychroerythraea. The latter is considered an obligate psychrophile with optimal growth at $8^{\circ} \mathrm{C}$, congruent with recorded bottom water values (Methe et al. 2005). Colwellia are often reported attached to surfaces (Brinkmeyer et al. 2003) but the occurrence of a flagellum suggests that if a highly similar bacterium occurs as a symbiont, it probably also has a free-living stage during which the flagellum is used. The presence of genes encoding a flagellum is reported from various environmentally-transmitted symbionts including the sulfur-oxidizing bacterium associated with the vent annelid Riftia pachyptila (Robidart et al. 2008). Both Colwellia species related to the Terua symbiont able to degrade organic compounds (Methe et

315 al. 2005). The $5.37 \mathrm{Mb}$ genome from C. psychroerythraea strain $34 \mathrm{H}$ has been sequenced and possesses genes encoding various enzymes able to break down high molecular weight organic compounds. Many of these proteins seem to be extracellular. This capability could benefit the mussel host living on bone material, in particular inter-vertebrate disks, if we for example hypothesize a role in collagen degradation similar to what is reported for the Osedax-associated

320 Oceanospirillales symbionts (Goffredi et al. 2014). It can be noted that two Colwellia species were cultured from animals, namely C. asteriadis from the skin of a starfish (Choi et al. 2010) and C. meonggei from a sea squirt (Kim et al. 2013). Potential interaction with their host was not investigated, but given that the $16 \mathrm{~S}$ rRNA sequence identified here is above $99 \%$ identical to that of cultivated Colwellia species, it might be possible to attempt cultivation of the Terua n. sp. symbiont, should more become available in the future. 


\section{Conclusion}

Terua $\mathrm{n}$. sp. Guadeloupe is the first mussel species identified from whale fall ecosystems in the Antilles arc. Its absence from previous fauna samplings at various cold seeps in the Gulf of

330 Mexico and western Atlantic suggests that it could be a true bone specialist, derived from ancestors found in the Pacific Ocean. Its dual symbiosis is unusual because most previously described boneassociated symbioses involved either only heterotrophic bacteria such as in the vestimentiferan Osedax, or sulfur-oxidizing autotrophs as in small mussels. Although the role of the Colwelliarelated bacterium in the symbiosis is not ascertained, the fact that a similar dual symbiosis occurs in

335 Terua n.sp. Guadeloupe 's relative Adipicola pacifica suggests that this could be a particular adaptation to bone habitats.

\section{Acknowledgments}

340 The material from Guadeloupe was obtained during the Karubenthos2 deep-sea cruise aboard ANTHEA funded by IRD and CNRS, and we thank Dr P. Bouchet and L. Corbari, the co-principal investigators, for their invitation. We thank P-Y Pascal for his participation in collecting the samples, the captain and crew of ANTHEA, and N. Léger for excellent technical assistance. We also thank the editor and two anonymous reviewers for comments that helped improve the manuscript.

345 Molecular work was funded by a grant from 'Institut Universitaire de France' to SD.

Altschul SF, Gish W, Miller W et al. Basic local alignment search tool. Mol Biol 1990;215:403-10.

Baco-Taylor A. Food-web structure, succession, and phylogenetics on deep-sea whale skeletons. PhD dissertation, University of Hawaii at Manoa 2002.

Bartoli G, Sarnthein M, Weinelt M, Erlenkeuser H, Garbe-Schönberg D, Lea DW. Final closure of Panama and the onset of northern hemisphere glaciation. Earth Planet Sci Lett 2005;237:3344.

Brinkmeyer r., Knittel K, Jurgens J et al. Diversity and structure of bacterial communities in Arctic versus Antarctic pack ice. Appl Env Microbiol 2003;69:6610-9.

Choi EJ, Kwon HC, Koh HY et al. Colwellia asteriadis sp. nov., a marine bacterium isolated from the starfish Asterias amurensis. Int J Syst Evol Microbiol 2010;60:1952-7.

Cole JR, Wang Q, Cardenas E et al. The ribosomal database project: improved alignments and new toolds for rRNA analysis. Nucl Acids Res 2009;37.

Colgan DJ, McLauchlan A, Wilson GDF et al. Histone H3 and U2 snRNA DNA sequences and arthropod molecular evolution. Aust J Zool 1998;46:419-37. 
Deming JW, Reysenbach AL, Macko SA et al. Evidence for the microbial basis of a chemoautotrophic invertebrate community at a whale fall on the deep seafloor: bonecolonizing bacteria and invertebrate endosymbionts. Miscrosc Res Tech 1997;37:162-70.

Distel D, Lane D, Olsen G et al. Sulfur-oxidizing bacterial endosymbionts - Analysis of phylogeny and specificity by $16 \mathrm{~S}$ ribosomal RNA sequences. J Bacteriol 1988;170:2506-10.

Distel DL, Lee HKW, Cavanaugh CM. Intracellular coexistence of methano- and thioautotrophic bacteria in a hydrothermal vent mussel. Proc Natl Acad Sci USA 1995;92:9598-602.

Dubilier N, Bergin C, Lott C. Symbiotic diversity in marine animals: the art of harnessing chemosynthesis. Nat Rev Microbiol 2008;6:725-40.

Duperron S. The diversity of deep-sea mussels and their bacterial symbioses. In: Kiel S (ed.). The Vent and Seep Biota. Springer, 2010, 137-67.

Duperron S, Halary S, Lorion J et al. Unexpected co occurence of 6 bacterial symbionts in the gill of the cold seep mussel Idas sp. (Bivalvia: Mytilidae). Env Microbiol 2008a;10:433-45.

Duperron S, Laurent MCZ, Gaill F et al. Sulphur-oxidizing extracellular bacteria in the gills of Mytilidae associated with wood falls. FEMS Microbiol Ecol 2008b;63:338-49.

Duperron S, Nadalig T, Caprais JC et al. Dual symbiosis in a Bathymodiolus mussel from a methane seep on the Gabon continental margin (South East Atlantic): 16S rRNA phylogeny and distribution of the symbionts in the gills. Appl Env Microbiol 2005;71:1694-700.

Duperron S, Sibuet M, MacGregor BJ et al. Diversity, relative abundance, and metabolic potential of bacterial endosymbionts in three Bathymodiolus mussels (Bivalvia: Mytilidae) from cold seeps in the Gulf of Mexico. Env Microbiol 2007;9:1423-38.

Eilers H, Pernthaler J, Glöckner FO et al. Culturability and In Situ abundance of pelagic bacteria from the North Sea. Appl Environ Microbiol 2000;66:3044-51.

Faure B, Schaeffer SW, Fisher CR. Species distribution and population connectivity of deep-sea mussels at hydrocarbon seeps in the Gulf of Mexico. Plos One 2015;10:e0118460.

Fisher CR, Brooks JM, Vodenichar JS et al. The co-occurence of methanotrophic and chemoautotrophic sulfur oxydixing bacterial symbionts in a deep-sea mussel. Mar Ecol 1993;14:277-89.

Folmer O, Black MB, Hoeh WR et al. DNA primers for amplification of mitochondrial cytochrome C oxidase subunit I from metazoan invertebrates. Mol Mar Biol Biotechnol 1994;3:294-9.

Fujiwara Y, Kawato M, Noda C et al. Extracellular and mixotrophic symbiosis in the whale-fall mussel Adipicola pacifica: a trend in evolution from extra- to intracellular symbiosis. PLOS One 2010;5:e11808.

Gaudron SM, Demoyencourt E, Duperron S. Reproductive traits of the cold seep mussel Idas modiolaeformis: from gametogenesis to larvall dispersal. Biol Bull 2012;222:6-16.

Goffredi SK, Yi H, Zhang Q et al. Genomic versatility and functional variation between two dominant heterotrophic symbionts of deep-sea Osedax worms. Isme J 2014;8:908-24. 
Gros O, Gaill F. Extracellular bacterial association in gills of "wood mussels.” Cah Biol Mar 2007;48:103-9.

Gustafson R, Turner R, Lutz R et al. A new genus and five new species of mussels (Bivalvia, Mytilidae) from deep-sea sulfide/hydrocarbon seeps in the Gulf of Mexico. Malacologia 1998;40:63-112.

Hassouna N, Michot B, Bachellerie J. The complete nucleotide-sequence of Mouse 28S ribosomalRNA gene - Implications for the process of size increase of the large subunit ribosomalRNA in higher Eukaryotes. Nucleic Acids Res 1984;12:3563-83.

Kim Y-O, Park S, Nam B-H et al. Colwellia meonggei sp. nov., a novel gammaproteobacterium isolated from sea squirt Halocynthia roretzi. Antonie Van Leeuwenhoek 2013;104:1021-7.

Laming SR, Duperron S, Cunha MR et al. Settled, symbiotic, then sexually mature: adaptive developmental anatomy in the deep-sea, chemosymbiotic mussel Idas modiolaeformis. Mar Biol 2014;161:1319-33.

Laming SR, Duperron S, Gaudron SM et al. Adapted to change: The rapid development of symbiosis in newly settled, fast-maturing chemosymbiotic mussels in the deep sea. Mar Environ Res 2015a;112:100-12.

Laming SR, Szafranski KM, Rodrigues CF et al. Fickle or Faithful: The roles of host and environmental context in determining symbiont composition in two Bathymodioline Mussels. Plos One 2015b;10:e0144307.

Lane D. 16S/23S rRNA sequencing. Nucleic Acid Techniques in Bacterial Systematics. New York: Stakebrandt E. and Goodfellow M. (Eds), John Wiley and Sons, 1991, 115-75.

Lorion J, Buge B, Cruaud C et al. New insights into diversity and evolution of deep-sea Mytilidae (Mollusca: Bivalvia). Mol Phyl Evol 2010;57:71-83.

Lorion J, Kiel S, Faure B et al. Adaptive radiation of chemosymbiotic deep-sea mussels. Proc Biol Sci 2013;280, DOI: 10.1098/rspb.2013.1243.

Methe BA, Nelson KE, Deming JW et al. The psychrophilic lifestyle as revealed by the genome sequence of Colwellia psychrerythraea $34 \mathrm{H}$ through genomic and proteomic analyses. Proc Natl Acad Sci U S A 2005;102:10913-8.

Meyer B, Kuever J. Molecular analysis of the distribution and phylogeny of dissimilatory adenosine-5'-phosphosulfate reductase-encoding genes (aprBA) among sulfur-oxidizing prokaryotes. Microbiology 2007;153:3478-98.

Ratnasingham S, Hebert PDN. BOLD: The Barcode of Life Data System (www.barcodinglife.org). Mol Ecol Notes 2007;7:355-64.

Robidart JC, Bench SR, Feldman RA et al. Metabolic versatility of the Riftia pachyptila endosymbiont revealed through metagenomics. Env Microbiol 2008;10:727-37.

Southward EC. The morphology of bacterial symbioses in the gills of mussels of the genera Adipicola and Idas (Bivalvia : Mytilidae). J Shellfish Res 2008;27:139-46. 
Thubaut J, Puillandre N, Faure B et al. The contrasted evolutionary fates of deep-sea chemosynthetic mussels (Bivalvia, Bathymodiolinae). Ecol Evol 2013;3:4748-66.

Won YJ, Jones WJ, Vrijenhoek RC. Absence of cospeciation between deep-sea mytilids and their thiotrophic symbionts. J Shellfish Res 2008;27:129-38.

Yu Y, Li H, Zeng Y et al. Phylogenetic diversity of culturable bacteria from Antarctic sandy intertidal sediments. Polar Biol 2010;33:869-75. 
Table legends :

Table 1 : PCR primers, cycling conditions (temperature and number of cycles) and number of clones analyzed for each of the genes sequenced from Terua n. sp. Primers were obtained from : (Hassouna et al., 1984; Lane 1991; Folmer et al. 1994; Colgan et al. 1998; BacoTaylor 2002; Meyer and Kuever 2007; Ratnasingham and Hebert 2007; Duperron et al. 2008a)

\section{Figure legends:}

Figure 1. Structural analysis of mussel specimens collected from sunken whale inter-vertebral

disk. A: Light micrograph of a freshly collected mussel at a depth of $800 \mathrm{~m}$. The shell appears smooth with a visible pink prodissoconch located at the umbo (arrow). B: ESEM image obtained from a piece of gill not dehydrated with solvents, showing seven gill filaments $(\mathrm{G})$ attached to the gill axis (Gs). C: EDX spectrum obtained from one of these gill filaments showing a peak of elemental sulfur (11 times higher than in EDX spectra obtained from mantle or foot [D]) suggesting that gill filaments harbor sulfur-oxidizing bacteria $(\mathrm{C}$ : carbon, $\mathrm{Ca}$ : calcium, $\mathrm{Cl}$ : chloride, Na: sodium, Mg: magnesium, O: oxygen, P: phosphorous, S: elemental sulfur). E: SEM views show the faint marginal groove (arrows) along the ventral edge of the gill and the numerous cilia on the frontal surface (E-F). F: Just below the ciliated zone of each gill filament (ZC), some bacteria could be observed (arrows) attached to the apical pole of the cells forming the lateral zone (ZL) of each gill filament.

Figure 2: SEM views of larval shell morphology. A: The larval shells (appearing in pink in Fig.1A) correspond to a small prodissoconch I (PI delineated by a white dot line) and a larger prodissoconch II (P II) with a total mean length of $445 \mu \mathrm{m}$. In adult individuals, the umbo is curved and prevents the observation of the prodissoconch I. The separation between prodissoconch II and the adult shell (dissoconch, D) is obvious. B: In a lateral view, the numerous tight growth lines of the prodissoconch II clearly suggests a lengthy planktotrophic larval development. The metamorphic line separating prodissoconch and dissoconch (D) is indicated by straight arrows while the periphery of the prodissoconch I is delineated by a dot line. C: In this dorsal view, once the right valve is removed, the small prodissoconch I (dot line) appears smooth while the larval shell (P II) is characterized by numerous concentric growth lines. D: Higher magnification focusing on the metamorphic line (arrows) that delineates the dissoconch characterized by smoother growth lines compared to the prodissoconch II. Prodissoconch I (PI); prodissoconch II (PII); dissoconch (D). 
Figure 3 : Phylogeny of Bathymodiolinae based on concatenate sequences of fragments of genes encoding mtCOI, mt16S rRNA and histone H3. A total of 1099 nucleotide positions were analyzed, positions with gaps and missing data were removed. A ML approach was used (see material and methods for detail). Scale bar represents $20 \%$ estimated sequence divergence. Only bootstrap values above 60 are displayed. The clade where sequences from this study cluster (in bold) and corresponding to the genus Terua sensu Thubaut 2013 is emphasized. Accession numbers of sequences used for this reconstruction are summarized in supplementary material S1.

385 Figure 4. Ultrastructural analysis (TEM) of the gill filaments. A: The ciliated zone of the gill filaments is free of bacteria and classically organized with several ciliated cells. This ciliated zone consists of a simple epithelium, which is in contact with a connective axis (CA), with cells harboring frontal cilia (F), latero-frontal cilia (LF), and lateral cilia (L). Fibroblasts (Fb). B: The lateral zone of each gill filament is organized as a pseudostratified epithelium organized around its

390 blood lacuna (BL). Each epithelial cell (BC) harbors numerous bacteria (arrows) throughout the lateral zone of the gill filament. C: Higher magnification of the lateral zone focusing on two bacteriocytes. The various bacterial shapes observed (rod-shaped or ovoid-shaped figures) could be due to the section orientation. Note that two morphotypes are observable, one displaying higher density in the periphery of the cells (one almost black, the other one gray). Extracellular bacteria are

395 located on the apical surface of the host cells in contact with microvilli (arrows). Bacteria are observed outside the bacteriocytes but also inside vacuoles (stars), each of which contains numerous bacteria with a shape similar to that of extra cellular ones. These bacteria probably became enclosed in the vacuoles by phagocytosis of extracellular bacteria. N: nucleus of the host cell.

400 Figure 5. Ultrastructural analysis of the bacteriocytes. A-C: The cytoplasm of the bacteriocytes contains residual bodies, characterized by whorls of membranes (stars), probably resulting from the intracellular digestion of extracellular bacteria as previously described in wood-mussels (Gros and Gaill, 2007). In these TEM views, most of the bacteria seem to be intracellular due to their location within large vacuoles resulting of phagocytosis. B: The first bacteriocyte (BC) of the lateral zone in 405 contact with the last eulateral cell (EL) harbors only extracellular bacteria (arrows) located between the microvilli (mv). C: microvilli (arrows) are obvious inside the vacuole containing numerous bacteria, some of them dividing. Note the two bacterial morphotypes easily distinguishable $(\mathbf{A}, \mathbf{C})$; a dark one (asterisks) with a black periphery of the bacterial cell and a clearer one (white triangles). BL: blood lacuna. N; nucleus of host cells. 
Figure 6: Phylogeny based on 16S rRNA-encoding gene sequences from bacterial symbionts associated with Bathymodiolinae. Names refer to the host species, clades comprising sulfuroxidizing, methane-oxidizing, methylotroph-related, and Colwellia-related bacteria are indicated. A total of 1197 nucleotide positions were analyzed. See materials and methods for detail. Scale bar

415 represents 5\% estimated sequence divergence. Bootstrap values above 60 are displayed. Sequences from this study in bold.

Figure 7: Fluorescence in situ hybridization on sections of gill filaments of Terua n. sp. Guadeloupe. Signal from probe Bthio-193 is in green in pictures A to D (Cy-3 labelled in A-B, Cy420 5labelled in C-D). Signal from probe Eub-338 is in red in A and B (Cy-5 labelled), signal from probe Alt1413 is in red in C and D (Cy-3 labelled). DAPI appear in blue in B and C. A-B: overview of several gill filaments, bacteria appear in red, sulfur-oxidizers in green or yellow. C-D: detail of gill filaments. Sulfur-oxidizing symbionts appear in green, Colwellia-related symbionts in red. Note the coexistence of the two symbionts in the gills. Scale bars represent $100 \mu \mathrm{m}$ (A) and $25 \mu \mathrm{m}$ (B425 D).

Supplementary material S1: accession numbers of gene sequences used in the phylogenetic tree displayed on figure 3. 

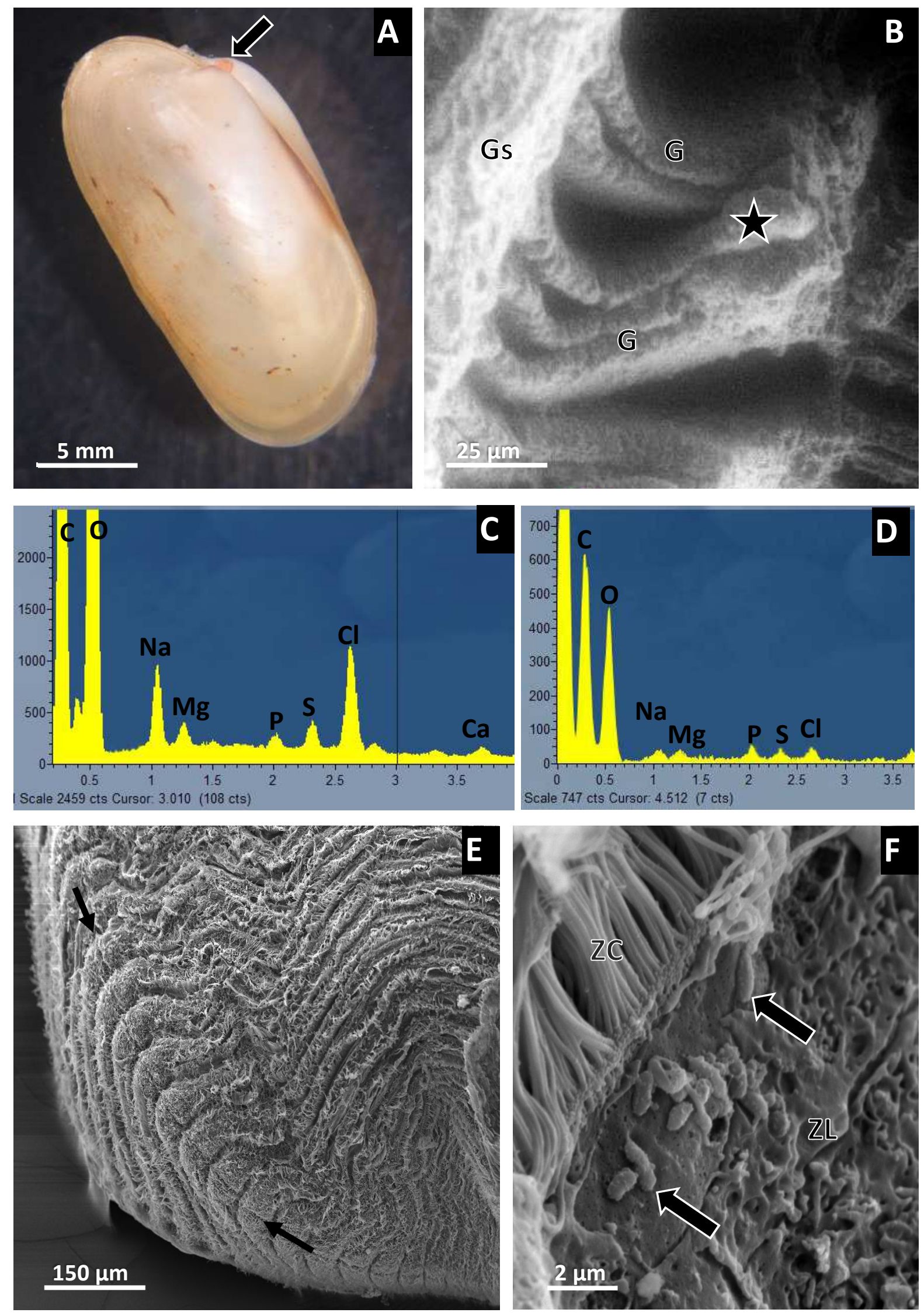

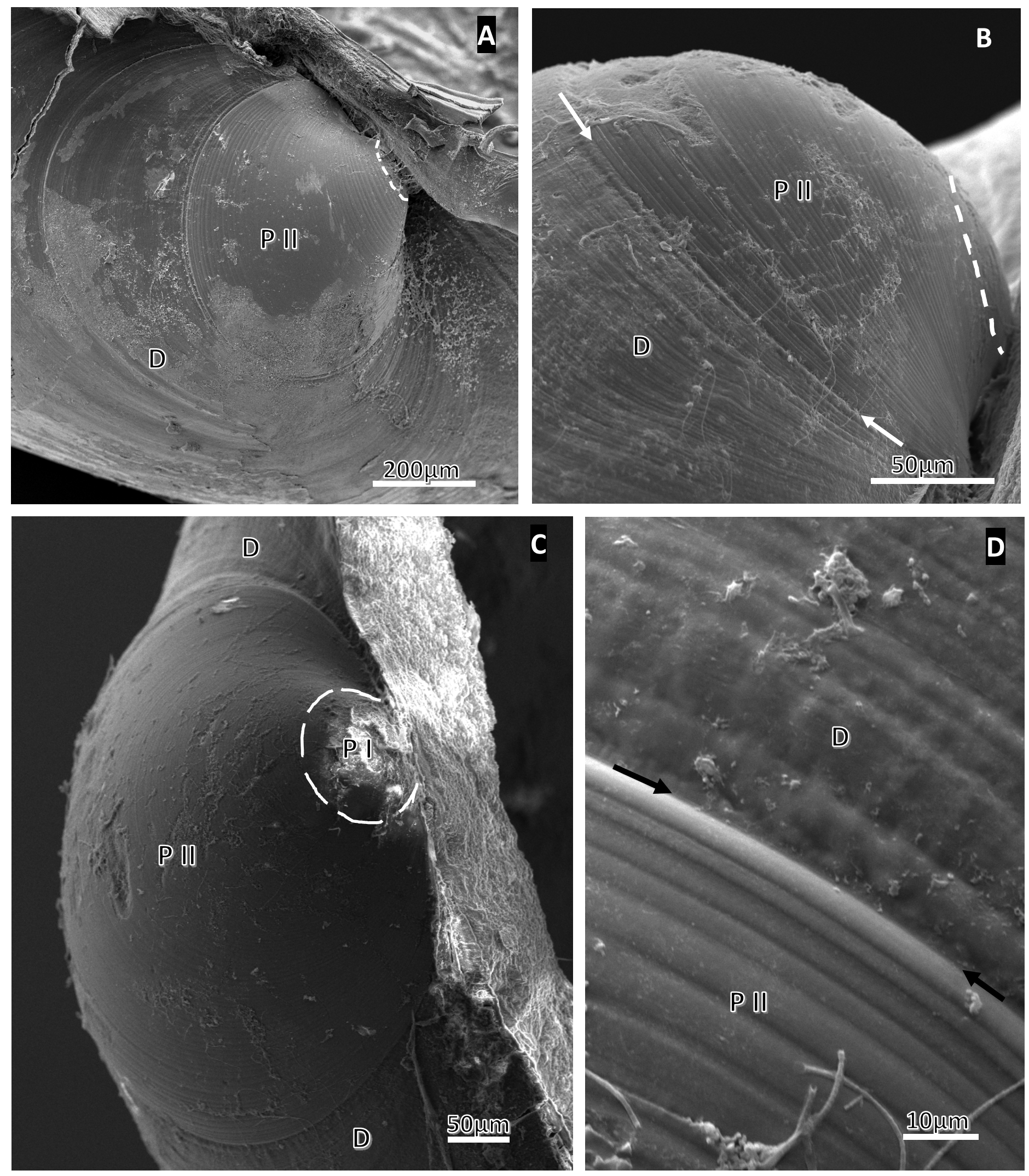


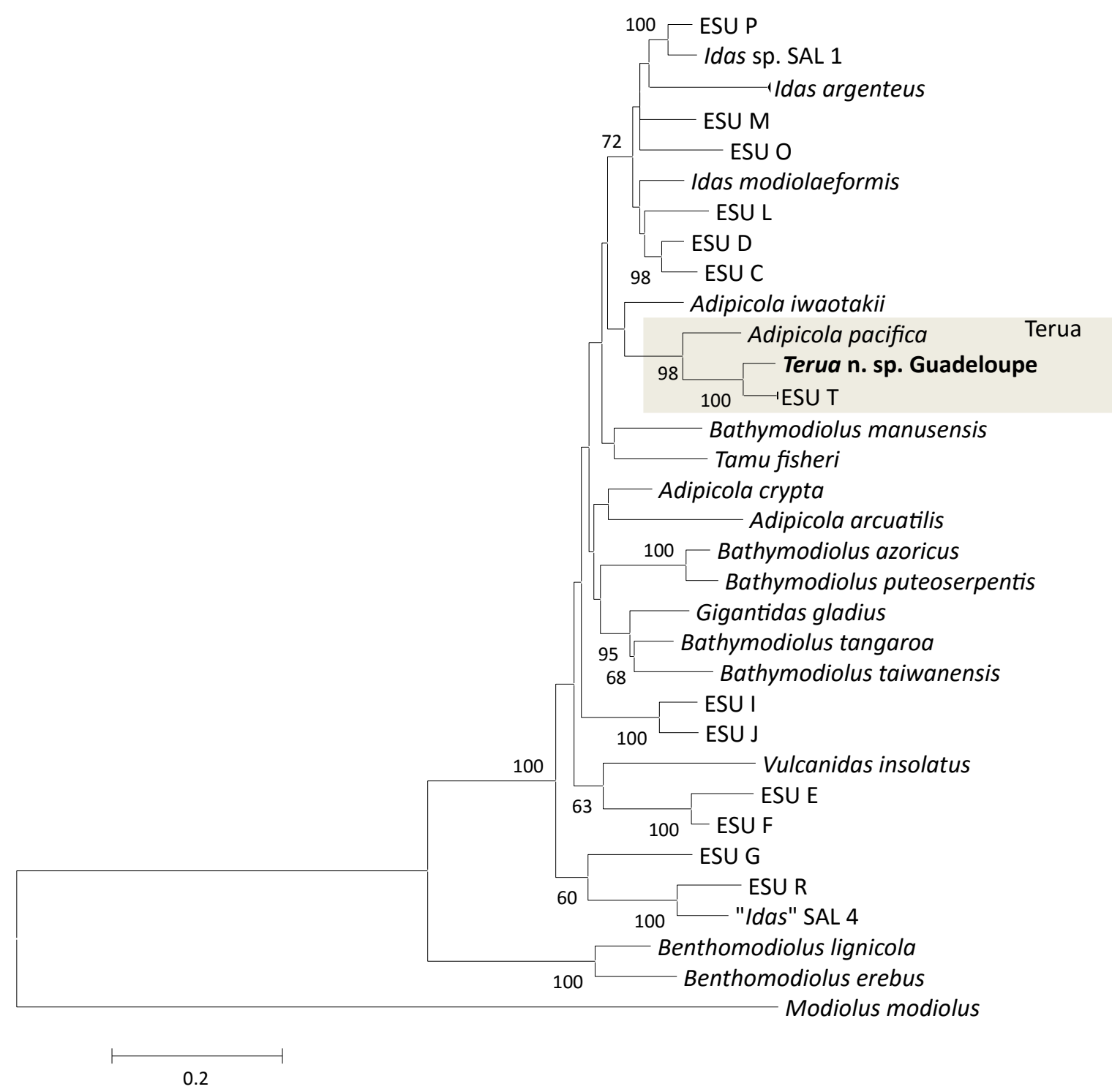




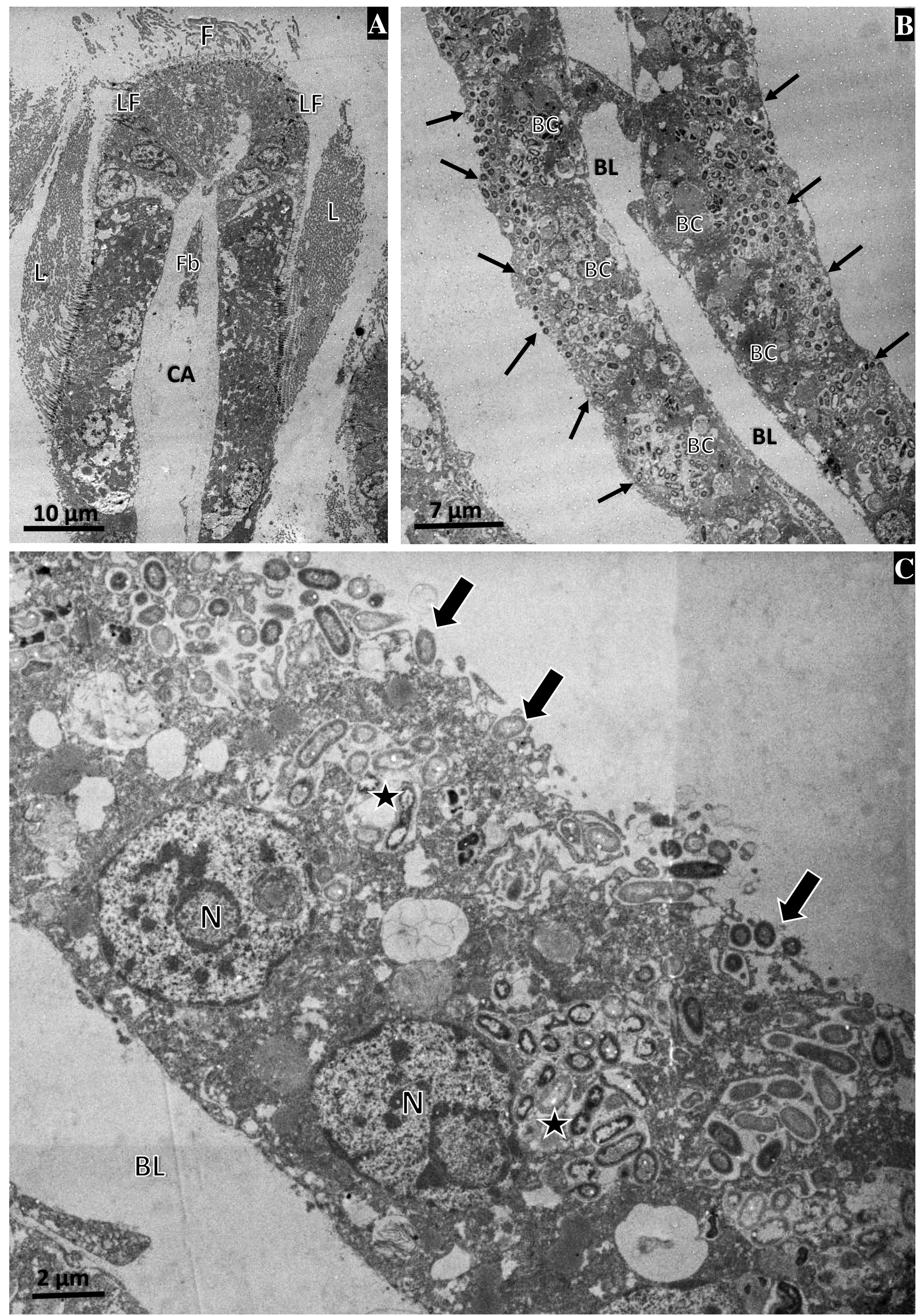




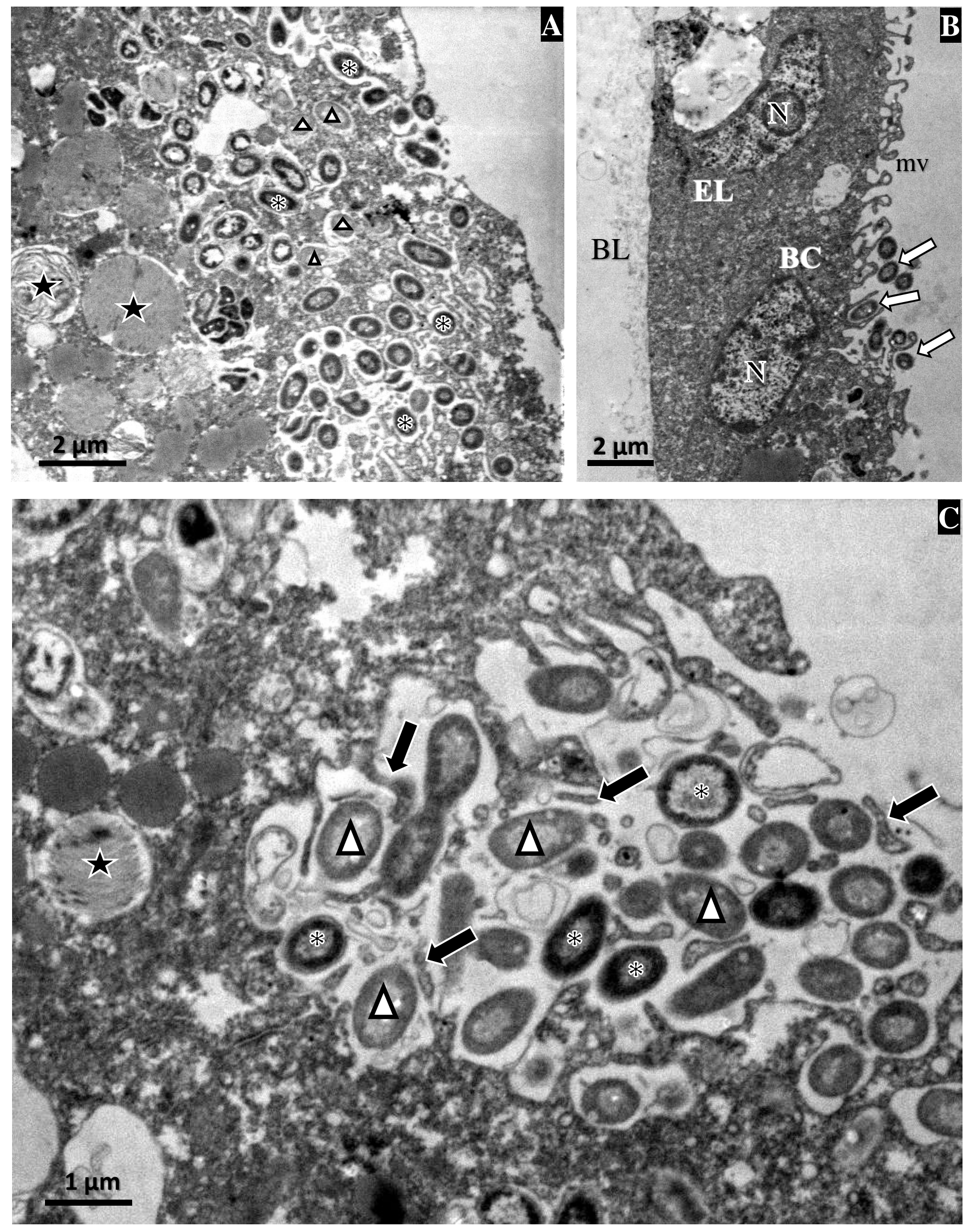




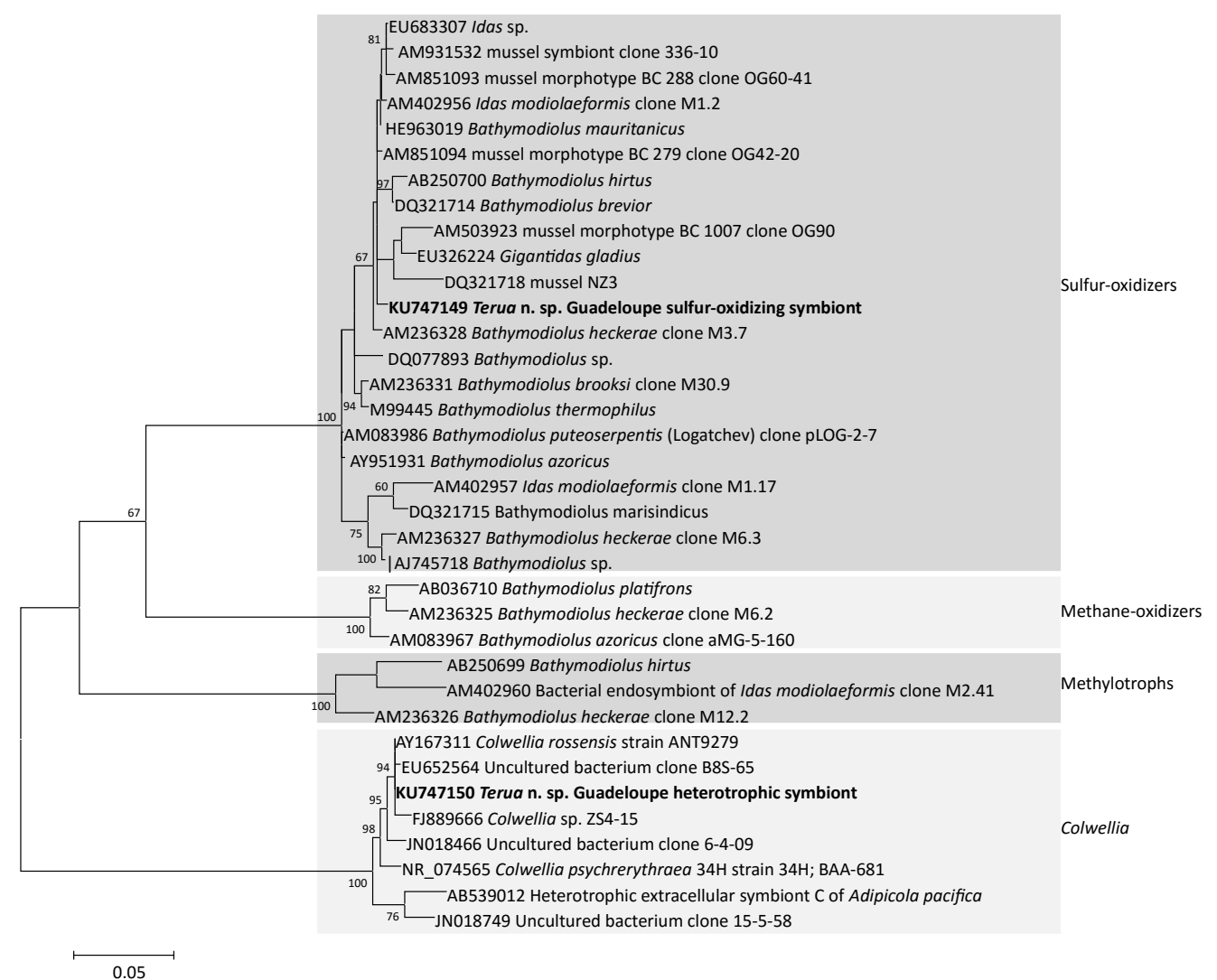




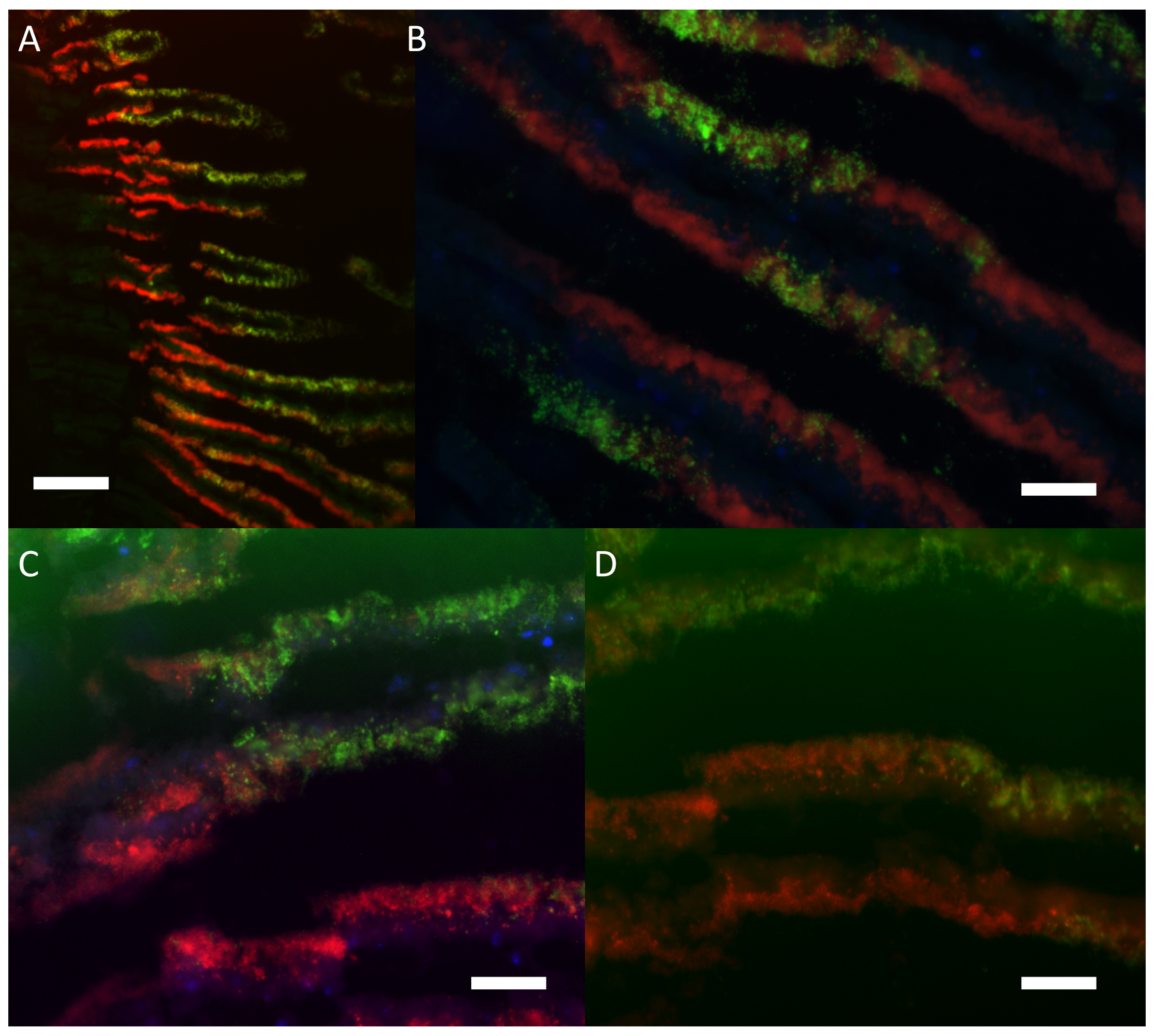




\begin{tabular}{|c|c|c|c|c|c|c|c|}
\hline & Gene & $\begin{array}{l}\mathrm{T}\left({ }^{\circ} \mathrm{C}\right) \text { and } \\
\text { cycles }\end{array}$ & $\begin{array}{l}\text { Primer } \\
\text { names }\end{array}$ & Primer sequences (5'?3') & $\begin{array}{c}\text { length } \\
\text { (nt) }\end{array}$ & Reference & $\begin{array}{l}\text { clones } \\
\text { analyzed }\end{array}$ \\
\hline \multirow[t]{8}{*}{ Host } & \multirow{2}{*}{\multicolumn{2}{|c|}{$\mathrm{COI} \mathrm{mtDN} / 50^{\circ} \mathrm{C}(35)$}} & H691 & GTRTTAAARTGRCGATCAAAAAT & \multicolumn{2}{|c|}{627 Duperron et al 2008} & 6 \\
\hline & & & LCO1490 & GGTCAACAAATCATAAAGATATTGG & & Folmer et al. 1994 & \\
\hline & \multirow[t]{2}{*}{ 28S rRNA } & \multirow[t]{2}{*}{$55^{\circ} \mathrm{C}(35)$} & C1prime & ACCCGCTGAATTTAAGCAT & 112 & 8 Hassouna et al. 1984 & \multirow[t]{2}{*}{9} \\
\hline & & & C4 & TCGGAGGGAACCAGCTACTA & & Hassouna et al. 1984 & \\
\hline & \multirow{2}{*}{\multicolumn{2}{|c|}{ mt16S rRN $55^{\circ} \mathrm{C}(35)$}} & $16 S A$ & GGARGTASGCCCTGCCCWATGC & & 6 Baco-Taylor 2002 & \multirow[t]{2}{*}{7} \\
\hline & & & LRJ & CTCCGGTTTGAACTCAGATCA & & Ratnasingham 2007 & \\
\hline & \multirow[t]{2}{*}{$\mathrm{H} 3$} & \multirow[t]{2}{*}{$57^{\circ} \mathrm{C}(35)$} & F1 & ATGGCTCGTACCAAGCAGACVGC & & 1 Colgan 1998 & \multirow[t]{2}{*}{12} \\
\hline & & & R1 & ATATCCTTRGGCATRATRGTGAC & & Colgan 1998 & \\
\hline \multirow[t]{4}{*}{ Bacteria } & \multirow[t]{2}{*}{ 16S rRNA } & \multirow[t]{2}{*}{$48^{\circ} \mathrm{C}(31)$} & $27 \mathrm{~F}$ & AGAGTTTGATCCTGGCTCAG & $\sim 1500$ & Lane 1991 & \multirow[t]{2}{*}{271} \\
\hline & & & $1492 R$ & GGTTACCTTGTTACGACTT & & Lane 1991 & \\
\hline & \multirow[t]{2}{*}{ APS } & \multirow[t]{2}{*}{$60^{\circ} \mathrm{C}(30)$} & APS1-FW & TGGCAGATCATGATYMAYGG & & Meyer Kuever 2007 & \multirow[t]{2}{*}{21} \\
\hline & & & APS4-RV & GCGCCAACYGGRCCRTA & & Meyer Kuever 2007 & \\
\hline
\end{tabular}




\begin{tabular}{|c|c|c|c|c|c|c|}
\hline Genus & Species & mtCOI & $28 \mathrm{~S}$ & mt16S & H3 & Ocean \\
\hline Modiolus & modiolus & FJ890501 & EF526455 & KF611732 & KF720595 & Atlantic \\
\hline Benthomodiolus & lignocola & AY275545 & AY781131 & KF611733 & KF720596 & Western Pacific \\
\hline \multirow[t]{3}{*}{ Benthomodiolus } & erebus & KF611694 & KF611699 & KF611734 & KF720597 & Northeast Pacific \\
\hline & ESU E & FJ937079 & GU065791 & 1KF611736 & KF720598 & Western Pacific \\
\hline & ESU F & FJ937127 & GU065809 & 9KF611737 & KF720599 & Western Pacific \\
\hline Vulcanidas & SAL3 & DQ340772 & 2DQ863946 & 6KF611738 & KF720600 & Western Pacific \\
\hline Vulcanidas & insolatus & FJ767936 & FJ767937 & KF611739 & KF720601 & Western Pacific \\
\hline \multirow[t]{4}{*}{ Tamu } & fisheri & AY649803 & AY781132 & HF545065 & 5 HF545148 & 3 Gulf of Mexico \\
\hline & SAL4 & DQ34077C & 6DQ863947 & 7KF611741 & KF720603 & Western Pacific \\
\hline & ESU R & FJ937239 & GU065877 & 7KF611742 & KF720604 & Western Pacific \\
\hline & ESU G & FJ937161 & GU065778 & 8KF611744 & KF720606 & Western Pacific \\
\hline Bathymodiolus & taiwanensis & GU966638 & BGU966641 & 1KF611746 & KF720608 & Western Pacific \\
\hline Bathymodiolus & tangaroa & AY608439 & AY781149 & KF611748 & KF720610 & Western Pacific \\
\hline Gigantidas & gladius & AY649802 & AY781134 & HF545085 & 5 HF545174 & 4 Western Pacific \\
\hline Adipicola & crypta & EU702319 & EU683298 & B KF611750 & KF720612 & Western Pacific \\
\hline \multirow[t]{3}{*}{ Nypamodiolus } & longissimus & DQ340773 & 3DQ863945 & 5 KF611752 & KF720614 & Western Pacific \\
\hline & ESU J & FJ937189 & GU065842 & 2KF611753 & KF720615 & Western Pacific \\
\hline & ESU I & FJ937188 & GU065774 & 4KF611754 & KF720616 & Western Pacific \\
\hline Bathymodiolus & manusensis & GU966637 & 7GU966642 & 2HF545059 & 9 KF720618 & Western Pacific \\
\hline Adipicola & arcuatilis & FJ937033 & GU065879 & 9KF611756 & KF720619 & Western Pacific \\
\hline Terua & ESU T & FJ937283 & GU065804 & 4KF611757 & KF720620 & Western Pacific \\
\hline Bathymodiolus & puteoserpentis & AY649796 & AY781151 & HF545053 & 3 HF545163 & 3 Mid-Atlantic Ridge \\
\hline Bathymodiolus & azoricus & AY649795 & AY781148 & KF611758 & KF720621 & Mid-Atlantic Ridge \\
\hline \multirow[t]{7}{*}{ Idas } & SAL 1 & DQ340775 & 5DQ863944 & $4 \mathrm{KF} 611761$ & KF720624 & Western Pacific \\
\hline & ESU P & FJ937222 & GU065846 & 6KF611762 & KF720625 & Western Pacific \\
\hline & ESU O & FJ937211 & GU065763 & 3KF611763 & KF720626 & Western Pacific \\
\hline & ESU D & EU702357 & EU683275 & 5 KF611765 & KF720628 & Western Pacific \\
\hline & ESU C & EU702376 & EU683260 & KF611766 & KF720629 & Western Pacific \\
\hline & ESU M & FJ937202 & GU065845 & 5KF611767 & KF720630 & Western Pacific \\
\hline & ESU L & FJ937193 & GU065767 & 7KF611768 & KF720631 & Western Pacific \\
\hline Adipicola & pacifica & HF545115 & HF545040 & HF545066 & 6 HF545161 & Western Pacific \\
\hline Adipicola & iwaotakii & EU702333 & EU683288 & 8 KF611770 & KF720633 & Western Pacific \\
\hline Idas & modiolaeformis & FJ158585 & FJ159555 & KF611772 & KF720635 & Eastern Atlantic, Mediterranean \\
\hline Idas & argenteus & LM992892 & 2LM992896 & 6LM992901 & 1 LM992897 & 7Atlantic \\
\hline Terua & n. sp. & KU747147 & KU747145 & 5 KU747146 & 6 KU747148 & 3 Antilles Arc \\
\hline Genus & Species & mtCOI & $28 \mathrm{~S}$ & mt16S & H3 & Ocean \\
\hline
\end{tabular}

